\title{
PENERAPAN MODEL PEMBELAJARAN 5E UNTUK MENINGKATKAN KETERAMPILAN PROSES SAINS DAN SIKAP ILMIAH SISWA KELAS VIII SMP NEGRI 6 KOTA BIMA
}

\author{
Yuri Rahmah ${ }^{1}$, Muh. Nasir ${ }^{2}$, Nikman Azmin ${ }^{3}$ \\ ${ }^{1}$ Mahasiswa Program Studi Pendidikan Biologi STKIP BIMA \\ 2,3Dosen Program Studi Pendidikan Biologi STKIP BIMA \\ E-mail: biologinikman@gmail.com
}

\begin{abstract}
Abstrak
Penelitian ini bertujuan untuk mengetahui peningkatan keterampilan proses sains dan sikap ilmiah siswa melalui penggunaan model pembelajaran 5E dalam pembelajaran IPA terpadu di kelas VIII SMP Negeri 6 Kota Bima. Jenis Penelitian yang digunakan adalah PTK. Desain penelitian ini dilaksanakan melalui dua tahap yaitu tahap siklus I dan tahap siklus II dengan tahapan-tahapan yaitu perencanaan, pelaksanaan tindakan observasi, evaluasi dan refleksi. Penelitian ini dilaksanakan di SMP Negeri 6 Kota Bima dan dilaksanakan selama 2 bulan. Subjek dalam penelitian siswa kelas VIII SMP Negeri 6 Kota Bima yang berjumlah 29 orang. Instrumen yang digunakan dalam penelitian ini yaitu berbentuk soal essay untuk mengukur keterampilan proses sain dan lembar observasi untuk mengukur sikap ilmiah siswa. Tehnik analisis data menggunakan rumus ketuntasan individu dan kalsikal serta untuk mengetahui peningkatan menggunakan N-Gain. Berdasarkan hasil penelitian didapatkan bahwa nilai ketuntasan klasikal pada siklus I sebesar 69,3\%, maka penelitian dilanjutkan ke siklus II, hasil ketuntasan klasikal yang didapatkan pada siklus II yaitu sebesar 100\%. Nilai peningkatan N-gain pada siklus I sebesar 0,43 meningkat pada siklus II menjadi sebesar 0,65. Sehingga dapat ditarik kesimpulan bahwa penerapan model pembelajaran $5 E$ dapat meningkatkan keterampilan proses sains dan sikap ilmiah siswa kelas VIII D SMP Negeri 6 Kota Bima.
\end{abstract}

Kata Kunci: Model Pembelajaran 5E, Keterampilan Proses Sains, Sikap Ilmiah

\section{PENDAHULUAN}

Keterampilan proses sains dan sikap masalah (Nasir dan Jufri, 2015). Keterampilan ilmiah merupakan kemampuan siswa dalam memahami, menemukan dan mengembangakan ilmu pengetahuan melalui metode ilmiah sebagaimana ilmuan menemukan konsep (Dash \& Padhi, 2015). Pembelajaran dengan pendekatan keterampilan proses sains lebih efektif di terapkan karena terjadi pengembangan kemampuan fisik dan mental baik individu maupun kelompok dalam memnyelesaikan proses sains meliputi mengamati, mengelompokan, menafsirkan, mengajukan pertanyaan, merumuskan hipotesis, melaksanakan percobaan, dan mengomunikasikan (Nasir dan Verawati, 2019). Dengan kata lain, KPS merupakan keterampilan yang memfasilitasi pembelajaran sains sehingga memungkinkan peserta didik untuk aktif dalam memecahkan masalah dan mengembangkan rasa 
tanggung jawab. Keterampilan proses sains dan sikap ilmiah sangat dibutuhkan dalam proses pembelajaran agar peserta didik aktif dan memahami mata pelajaran khususnya mata pelajaran IPA. Pembelajaran Ilmu Pengetahuan Alam (IPA) dapat berlangsung jika peserta didik berpatisipasi aktif dalam memanfaatkan keterampilan proses sains dan sikap ilmiah. Keterampilan proses sains merupakan keterampilan yang digunakan peserta didik untuk menyelidiki dunia di sekitar mereka dan membangun konsep ilmu pengetahuan (Merduwati dkk, 2019).

Hasil observasi yang dilakukan di SMPN 6 Kota Bima khususnya pada kelas VIIID dan wawancara dengan guru mata pelajaran IPA menunjukkan bahwa pencapaian hasil belajar peserta didik masih kurang optimal yaitu masih ada siswa yang belum mencapai KKM (30\%). Asumsi dasar yang menyebabkan pencapaian hasil belajar peserta didik kurang optimal adalah kurang aktifnya peserta didik dalam proses pembelajaran, proses pembelajaran pada Mata Pelajaran IPA cenderung masih terfokus pada guru, model pembelajaran yang digunakan masih konvensional, peran serta peserta didik belum menyeluruh sehingga menyebabkan diskriminasi dalam kegiatan pembelajaran. Peserta didik yang aktif dalam proses pembelajaran, lebih aktif dalam bertanya dan menggali informasi dari guru maupun sumber belajar yang lain sehingga cenderung memiliki pencapaian kompetensi belajar yang lebih tinggi. Peserta didik yang cenderung pasif dalam proses pembelajaran, hanya menerima pengetahuan yang datang dari guru saja sehingga pencapaian kompetensinya lebih rendah.

Berdasarkan pertimbangan di atas, maka perlu penggunaan suatu model pembelajaran yang mampu melibatkan peran serta peserta didik secara menyeluruh sehingga kegiatan pembelajaran tidak hanya didominasi oleh peserta didik tertentu saja. Salah satu model pembelajaran yang mampu meningkatkan keterampilan proses sains dan sikap ilmiah adalah model 5E (Nasir dkk, 2019). Prinsip dasar dalam model pembelajaran $5 \mathrm{E}$ adalah memberi kesempatan pada peserta didik untuk menemukan sendiri, menerapkan, dan menggunakan cara-cara belajar yang sesuai. Peserta didik harus membangun pengetahuannya secara individual di dalam pikirannya. Aplikasi 5E terdiri dari lima fase, yaitu engagement, exploration, explanation, elaboration/extension, dan evaluation (Nasir dan Jufri, 2015). Setiap fase dalam model siklus belajar (Learning Cycle) 5E memiliki fungsi khususuntuk menyumbang proses belajar dikaitkandengan kegitaan mental dan fisik siswa sertastrategi yang dikerjakan guru sangat untuk mendukung tercapainya pemahaman konsep siswa terhadap konsep-konsep yang kompleks. Berupa rangkaian tahap-tahap fase yang 
diorganisasi sedekimian rupa, meliputi pembangkitan minat, eksplorasi, penjelasan, elaborasi, dan evaluasi. Pada tahapengagement ini dapat meningkatkan keterampilan proses sains dan membangkitkan rasa ingin tahu peserta didik tentang materi yang dipelajari, peserta didik mengajukan pertanyaan, mendefinisikan masalah dan memecahkan masalah agar peserta didik fokus pada tugastugas mereka (Suastra, 2009).

\section{METODE}

Penelitian dilaksanakan di SMP Negeri 6 Kota Bima yang beralamat di Jln. Sukun No. 1 Karara Kecamatan Raba selama 3 bulan yaitu mulai bulan Juli sampai bulan September.

Penelitian ini di fokuskan pada penggunaan model pembelajaran $5 \mathrm{E}$ untuk mengukur keterampilan proses sains dan sikap ilmiah. Desain penelitian PTK sebagai berikut:

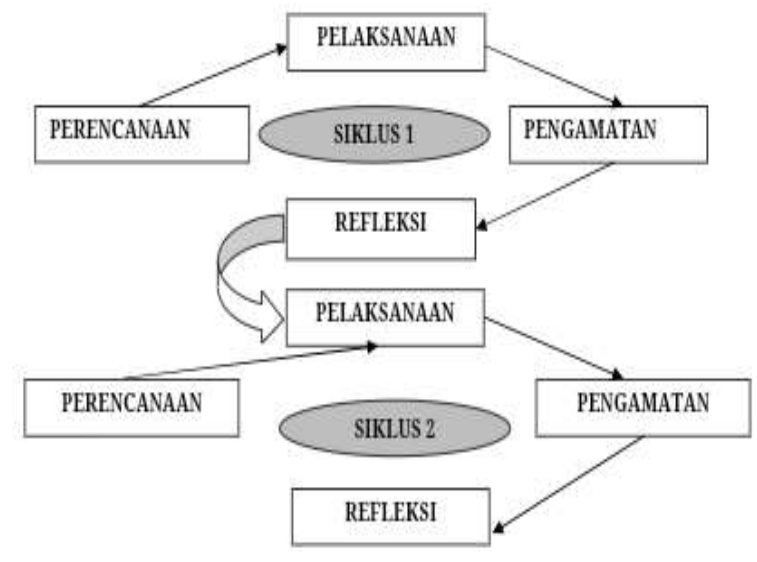

Gambar 1. Desain Penelitian

Instrumen penelitian yang digunakan yaitu

Tes Tertulis untuk mengukur keterampilan proses sains dimensi soal mengacu pada indikator keterampilan proses sains, berbentuk soal essay dengan jumlah soal sebanyak 5 soal dan Lembar Observasi digunakan untuk mengukur sikap ilmiah siswa.

Adapun prosedur penelitian ini terdiri dari 2 siklus kegiatan yaitu:

1. Siklus I yaitu Perencanaan dimana Mengkaji silabus dan membuat Rencana Pelaksanaan Pembelajaran dan Menyiapkan alat evaluasi. Tahap Pelaksanaan, tahap Pelaksanaan Siklus I kelas dibuat berkelompok, di dalam tiap kelompok terdapat siswa yang memiliki tingkat pengetahuan yang heterogen sesuai dengan langkah model 5E. Observasi, pada tahap Observasi dilakukan oleh observer selama proses pembelajaran berlangsung mengamati observasi dilakukan untuk mengolah data dari lembar observasi yang telah diisi oleh observer tentang pelaksanaan kegiatan belajar mengajar. Selanjutnya Refleksi

2. Siklus II yaitu Prosedur pada siklus kedua pada dasarnya sama dengan siklus pertama, hanya saja pada siklus kedua dilakukan perbaikan terhadap kekurangan pada siklus pertama dari segi perencanaan maupun segi pelaksanaan tindakan.

Analisis Data secara deskriptif, untuk melihat ketuntasan belajar siswa menggunakan Rumus ketuntasan individu dengan KKM 70 dan ketuntasan klasikal $80 \%$. 
Untuk mengetahui adanya peningkatan keterampilan proses sains dan sikap ilmiah dengan menggunakan rumus $\mathrm{N}$-gain. Kriteria nilai N-Gain mengacu pada Nasir (2015) sebagai berikut:

Tabel 1. Kriteria Gain Ternormalisasi

\begin{tabular}{|c|c|}
\hline Persentase & Klasifikasi \\
\hline N-gain $>70$ & Tinggi \\
\hline $30 \leq \mathrm{N}$-gain $\leq 70$ & Sedang \\
\hline N-gain $<30$ & Rendah \\
\hline
\end{tabular}

\section{HASIL DAN PEMBAHASAN}

\section{Siklus 1}

Hasil penilaian test dalam tahap ini menunjukkan bahwa kelas menjadi lebih berwarna, hal ini ditunjukkan oleh suasana presentasi dari masing-masing kelompok dan tanggapan dari kelompok lain. Pada siklus ini sebagian besar kegiatan telah terlaksana berdasarkan rencana pembelajaran. Tindakan perbaikan yang dilakukan oleh guru pada siklus pertama membawa dampak positif terhadap kegiatan diskusi dan hasil belajar siswa. Hal ini terlihat pada proses evaluasi yang dilakukan pada akhir siklus. Evaluasi dilaksanakan dalam berbagai aspek untuk mengetahui peningkatan keterampilan proses sains dan sikap ilmiah siswa melalui observasi dan test.
Tabel 2. Data hasil pretest dan posttest siklus I

\begin{tabular}{|c|c|c|c|c|}
\hline & Pre test & $\begin{array}{l}\text { Post } \\
\text { test }\end{array}$ & $\begin{array}{l}\text { N- } \\
\text { Gain }\end{array}$ & $\begin{array}{c}\text { Keteranga } \\
\mathrm{n}\end{array}$ \\
\cline { 1 - 4 } $\begin{array}{c}\text { Jumla } \\
\text { h }\end{array}$ & 1290 & 2010 & 12,55 & $\begin{array}{c}\mathrm{T}=18 \\
\text { Siswa } \\
\text { TT=11 } \\
\text { Siswa }\end{array}$ \\
\cline { 1 - 2 } $\begin{array}{c}\text { Rata- } \\
\text { Rata }\end{array}$ & 44,4 & 69,3 & 0,43 & \multicolumn{2}{|c|}{$62,06 \%$} \\
\hline \multicolumn{2}{|c|}{ Ketutasan Klasikal } & \multicolumn{2}{|c|}{} \\
\hline
\end{tabular}

Berdasarkan Tabel 2 diatas siswa dinyatakan tuntas secara individu ssebanyak 18 siswa dan tidak tuntas sebanyak 11 siswa. Sementara ketuntasan Klasikal baru tercapai sebanyak $62,06 \%$, nilai ini belum mencapai standard ketuntasan kalsikal yang telah ditetapkan yaitu $80 \%$. Karena tidak memenuhi ketuntasan klasikal, maka dilanjutkan ke siklus ke II. Di lihat nilai (N-Gain) sebesar 0,43 atau (43\%) nilai ini berada pada kategori sedang, hal ini menunjukkan adanya peningkatan pemahaman atau penguasaan konsep siswa ratarata sebesar $43 \%$ setelah pembelajaran dilakukan dengan penggunaan model pembelajaran 5E materi Mengidentifikasi Struktur pada Tulang. Hal ini diungkapkan Nasir (2015) dan Pratiwi (2016) bahwa model pembelajaran 5E adalah suatu model pembelajaran yang berpusat pada pelajar (student centered) yang dapat meningkatkan proses sains dan sikap ilmiah. 
Tabel 3. Hasil Observasi Sikap Ilmiah Siswa Siklus I

\begin{tabular}{|c|c|c|c|c|c|c|c|c|c|}
\hline \multicolumn{10}{|c|}{ Sikap Illmiah } \\
\hline \multirow[b]{3}{*}{ Nilai } & \multicolumn{3}{|c|}{ Sikap Ingin Tahu } & \multicolumn{3}{|c|}{ Sikap Kitis } & \multicolumn{3}{|c|}{ Sikap Jưur } \\
\hline & $\mathrm{A}$ & $B$ & $C$ & $\mathrm{~A}$ & $B$ & C & $A$ & $B$ & $c$ \\
\hline & 120 & 56 & 50 & 46 & 41 & 52 & 73 & 57 & 71 \\
\hline Rata-rata & 41 & 19 & 17 & 15 & 14 & 17 & 25 & 19 & 24 \\
\hline Jumlah & \multicolumn{3}{|c|}{$7,7 \%$} & \multicolumn{3}{|c|}{$4,6 \%$} & \multicolumn{3}{|c|}{$6,8 \%$} \\
\hline Total & \multicolumn{9}{|c|}{$1,39 \%$} \\
\hline
\end{tabular}

Berdasarkan data pada Tabel 3 diatas diketahui bahwa terjadi peningkatan pada sikap ilmiah, namun di rasa masih belum optimal. Pada observasi siklus I, peneliti menemukan beberapa kendala pada saat pembelajaran berlangsung, yaitu: Kurangnya siswa bertanya kepada guru atau kepada siswa lain jika ada materi yang belum dipahami. Dalam berdiskusi untuk memecahkan masalah, siswa masih canggung dan tidak serius. Sebagian besar siswa tidak serius dalam mengerjakan tugas dari guru, hal ini juga diungkapkan oleh Gayatri (2017).

\section{Refleksi Tindakan Siklus I}

Pada kegiatan siklus I, berkenaan hasil belum mencapai target ketuntasan klasikal $80 \%$ siswa, hal ini disebabkan oleh proses pembelajaran yang masih kurang efektif dan kurang maksimal dalam menerangkan model pembelajaran 5E. Oleh karena itu pada siklus kedua peneliti lebih memaksimalkan penerapan model pembelajaran 5E, supaya proses pembelajaran semakin dapat dipahami. Pada siklus I menunjukkan bahwa tidak ada permasalahan dalam perumusan perencanaan tindakan (RPP).

\section{Siklus II}

Siklus kedua penelitian dilaksanakan pada hari Kamis tanggal 29 Agustus 2019. Pada rencana tindakan siklus II peneliti tetap menerapkan model pembelajaran $5 \mathrm{E}$, dengan model pembelajaran ini diharapkan dapat lebih membantu untuk meningkatkan keterampilan proses sains dan sikap ilmiah siswa.

Pada siklus ke II, peneliti berusahan untuk terus menggali kelemahan pembelajaran pada siklus I, Berikut data hasil pretest dan posttest siklus II

Tabel 4. Data hasil pretest dan posttest siklus II

\begin{tabular}{|c|c|c|c|c|}
\hline & $\begin{array}{c}\text { Pre } \\
\text { test }\end{array}$ & $\begin{array}{l}\text { Post } \\
\text { test }\end{array}$ & $\begin{array}{l}\text { N- } \\
\text { Gain }\end{array}$ & Keterangan \\
\hline Jumlah & 1330 & 2370 & 19,03 & $\begin{array}{c}\text { T=29 } \\
\text { Siswa }\end{array}$ \\
\cline { 1 - 4 } $\begin{array}{c}\text { Rata- } \\
\text { Rata }\end{array}$ & 45,8 & 81,7 & 0,65 & \\
\hline \multicolumn{3}{|c|}{ Ketutasan Klasikal } & \multicolumn{2}{|c|}{$100 \%$} \\
\hline
\end{tabular}

Berdasar tabel 4 diatas dapat terlihat terjadi peningkatan rata-rata nilai siswa dari 45,8 menjadi 81,7 , semua siswa sebanyak 29 orang tuntas secara individu, dan ketuntasan klasikal mencapai $100 \%$ melebihi standar ketuntasan klasikal yang telah ditetapkan yaitu 80\%. Selain itu juga terjadi peningkatan keterampilan proses sains siswa sebesar 0,65 pada kategori sedang. Hasil ini menunjukan bahwa penerapan model pembelajaran $5 \mathrm{E}$ terbukti dapat meningkatkan keterampilan 
proses sains siswa.

Hasil observasi sikap ilmiah siswa pada siklus II juga mengalami peningkatan yang signifikan, hal ini terlihat pada tabel sebagai berikut:

Tabel 5. Hasil Observasi Sikap Ilmiah Siswa Siklus II

\begin{tabular}{|c|r|c|c|c|c|c|c|c|c|}
\hline \multicolumn{10}{|c|}{ Sikap Ilmiah } \\
\hline \multirow{4}{*}{} & \multicolumn{2}{|c|}{ Sikap Ingin Tahu } & \multicolumn{2}{|c|}{ Sikap Kritis } & \multicolumn{3}{|c|}{ Sikap Jujur } \\
\cline { 2 - 10 } & A & B & C & A & B & C & A & B & C \\
\cline { 2 - 10 } Nilai & 12 & 12 & 100 & 12 & 100 & 12 & 12 & 120 & 100 \\
& 0 & 0 & & 0 & & 0 & 0 & & \\
\hline Rata-rata & 41 & 41 & 34 & 41 & 34 & 41 & 41 & 41 & 34 \\
\hline Jumlah & \multicolumn{10}{|c|}{$11,6 \%$} & \multicolumn{3}{|c|}{$11,6 \%$} & \multicolumn{3}{|c|}{$11,6 \%$} \\
\hline Total & \multicolumn{10}{|c|}{$34,8 \%$} \\
\hline
\end{tabular}

Pada siklus ke II ini pembelajaran terus mengalami peningkatan yang signifikan, ini dibuktikan dengan suasana pembelajaran yang terjadi dua arah, diskusi kelompok dalam rangka memecahkan masalah berlangsung dengan alot, siswa lebih serius dalam mengerjakan tugas yang diberikan oleh guru, pertanyaan-pertanyaan yang dilontarkan guru dapat dijawab dengan tepat, suasana posttest berlangsung dengan hidmat dan penuh keseriusan. Siswa berusaha untuk bertanya terhadap apa yang belum mereka mengerti dan pahami. Pada siklus II penelitian telah berhasil, sebagian besar rencana proses pembelajaran telah terlaksana dengan baik. Pada proses pembelajaran siklus II ini ditemukan satu kendala yaitu siswa belum dapat membuat simpulan sendiri terhadap materi yang telah diberikan oleh guru. Walaupun masih belum mencapai $100 \%$ tapi di siklus II keselurahan siswa sudah ada peningkatan sikap ilmiah dengan menggunakan model $5 \mathrm{E}$ dalam pembelajaran IPA.

Tabel 6. Rekapitulasi Pretest dan Posttest Siklus I dan Siklus II

\begin{tabular}{|c|c|c|c|c|c|c|}
\hline Unian & $\begin{array}{l}\text { Pretest } \\
\text { Silus I }\end{array}$ & $\begin{array}{l}\text { Posttest } \\
\text { Salus I }\end{array}$ & N-Gain & $\begin{array}{l}\text { Pretest } \\
\text { Sillus I }\end{array}$ & $\begin{array}{l}\text { Postlest } \\
\text { StHus II }\end{array}$ & N-Gain \\
\hline Jumlah & 1290 & 2010 & 1255 & 1330 & 2370 & 19,03 \\
\hline Rata-rata & 4., & 693 & 0,43 & 458 & 81.7 & 0,65 \\
\hline
\end{tabular}

Nilai pretest dan posttest siklus I mengalami peningkatan, hal ini dapat dilihat dari perolehan nilai rata-rata pretest siswa pada siklus I adalah 44,4 dan rata-rata posttest adalah 69,3. Kemudian jika dilihat dari penguasaan konsep yang ditunjukkan dengan $\mathrm{N}$-Gain, rata-rata $\mathrm{N}-$ Gain sebesar 0.43 , hal ini menunjukkan terjadi peningkatan pemahaman dan penguasaan konsep sebesar 43\%. Pada siklus II nilai pretest dan postest mengalami peningkatan, hal ini dapat dilihat dari perolehan nilai rata-rata pretest siswa pada siklus II adalah 45,8 dan rata-rata postest adalah 81,7. Kemudian jika dilihat dari penguasaan konsepyang ditunjukkan dengan $\mathrm{N}$ Gain, rata-rata N-Gain sebesar 0.65 , hal ini menunjukkan terjadi peningkatan pemahaman dan penguasaan konsep sebesar $65 \%$. 


\section{KESIMPULAN}

Berdasarkan hasil penelitian maka dapat diambil kesimpulan bahwa Penerapan model pembelajaran 5E dapat meningkatkan Keterampilan proses sains dan sikap ilmiah siswa kelas VIII D SMP Negeri 6 Kota Bima. Dengan nilai ketuntasan klasikal pada siklus I sebesar 69,3\%, dan ada siklus II meningkat menjadi $100 \%$. Nilai peningkatan $\mathrm{N}$-gain pada siklus I sebesar 0,43 meningkat pada siklus II menjadi sebesar 0,6 .

\section{DAFTAR PUSTAKA}

Dash, P ., \& Padhi, S.K. 2015. Constructivism And Science Performing Skill Among Elementary Students : A Study, India Journal Of Applied Reseacrh.

Gayatri, E. R. P., Bahar, A., \& Handayani, D. (2017). Perbandingan Penerapan Model Pembelajaran Learning Cycle (5E) dan Two Stay Two Stray. Alotrop, 1(1)

Merduwati, S., Nasir, M., \& Ferawati, F. (2019). Pengembangan Lembar Kerja Peserta Didik (LKPD) Berbasis Learning Cycle 5e Dilengkapi Peta Konsep. In Proceeding National Conference: Education, Social Science, and Humaniora (Vol. 1, No. 1, pp. 93-100).

Nasir, M., \& Jufri, A. W. (2015). Pengembangan Perangkat Pembelajaran Model 5E untuk Meningkatkan Kemampuan Berpikir Kritis Siswa. Jurnal Penelitian Pendidikan IPA, 1(2).
Nasir, M., \& Verawati, V. (2019, February). Pengaruh Penggunaan Lembar Kerja Siswa (LKS) Model Pembelajaran 5e Terhadap Hasil Belajar Biologi Siswa Kelas X SMA Negeri 1 Bolo Tahun Pelajaran 2018/2019. In Prosiding Seminar Nasional II APPPI NTB 2018 (Vol. 1, No. 1).

Nasir, M., Fahruddin, F., Olahairullah, O., \& Sumarni, S. (2019). Implementasi Model Pembelajaran 5E Berorientasi Kerangka Kualifikasi Nasional Indonesia (KKNI) pada Revolusi Industri 4.0 Untuk Meningkatkan Hasil Belajar Siswa SMAN 3 Kota Bima. In Proceeding National Conference: Education, Social Science, and Humaniora (Vol. 1, No. 1, pp. 88-92).

Pratiwi, D. D. (2016). Pembelajaran learning cycle 5E berbantuan geogebra terhadap kemampuan pemahaman konsep matematis. Al-Jabar: Jurnal Pendidikan Matematika, 7 (2), 191202

Suastra, I.W. 2009. Pembelajaran Sains Tehnik: Mendekatkan Siswa dengan Lingkungan Alamiah dan Sosial Budayanya. Universitas Pendidikan Ganesha. Singaraja. 